Annals of the Social Science Council of Nigeria

\title{
A COMMENT ON CENTRAL-LOCAL GOVERNMENT RELATIONS IN NIGERIA
}

This paper contains some comments on the relationship between the central government as the local governments. One of the principal objectives is to highlight the problems underlying the third-tier of government and its impact on development at the grassroots. Functions either are assigned to levels of government in Nigeria exclusively or concurrently. Local governments in Nigeria are constitutionally assigned specific functions for which they are best positioned to perform. Consequently, whatever functions are specifically allocated to any level of government could be performed by that level without reference to any other level of government.

Both the 1979 Nigerian Constitution (fourth schedule) and the 1976 Guidelines for Local Government Councils list functions to be performed by Local Government Councils either exclusively or in conjunction with state governments and other organizations. There is, thus, constitutional guarantee for local governments.

Yet the mere fact that the state government "shall ensure their existence under the law..." suggests that the 'existence' of local governments depends somehow on state governments and, by extension, on the Federal Government, especially when the supremacy of federal laws over those of the other two levels of government is recognized Thus, constitutional provision concerning functions of various tiers of government is superficial because local governments are still controlled by the States who are in turn controlled by the Federal government.

Control over local governments is exercised in various ways. Annual budgets, development plans and bye-laws of local governments are vested and approved by the state governments before they become operational, while, their request for bank loans must be guaranteed by the state government Initiative is stultified by frequent changes of policies and guidelines emanating from the central government All of this is counterproductive because local governments are unable to plan.

The federal government may seek to influence local governments through macroeconomic policies for example; the economic recession has forced the federal government to introduce a number of measures which have in turn affected local governments.

Administrative control of local government council activities is also exercised through control of local expenditure, ostensibly in the interest of economies of scale or uniformity of service. Although the latter may be technically and economically feasible, its desirability is difficult to justify. Two 
considerations are paramount here: the 'externalities' or spill-over effect of a service, and its level of priority considered from the viewpoint of positive social justice.

Administrative control has often proved difficult to effect, bearing in mind that quite apart from the externalities of particular services, gross disparities between local government areas in the general level of public service and investment, or indeed, the whole standard of living, can breed a degree of discontent which can threaten the peace, integrity and stability of nation-states.

Finally, judicial control is yet to play a significant role in centre - local relations. Local governments in Nigeria grew out of Acts of Parliament (or their substitute structures under military rule) and so tended to be controlled by the same instruments.

Second, because of widespread illiteracy, most citizens did not know their rights and so did not ask for them. Third, local government councils already seem to be adequately controlled by their respective state governments so that judicial control failed to spark most minds. However, the clear fact that any informed citizen can challenge any council that tramples on his freedom in Nigeria suggests that judicial control is a potential control measure for contemporary and future Nigeria.

Within the Nigerian political system, the local government constitutes the most critical level of government at which the momentum to sustain national development can be created since it is the closest level of government to the people, representing in some communities the only semblance of authority beyond the traditional. Thus, its relationship with the centre must be meticulously guarded. Unfortunately, the 'intergovernmental' character of local government works against any absolute sense of freedom, hence the inevitability of central control

\section{I.B.BELLO-IMAM}

NTSER, Ibadan. 